Table 2 Effect of Normalizing on Tensile Properties.

\begin{tabular}{|c|c|c|c|c|c|c|c|}
\hline \multirow[b]{2}{*}{ Steel } & \multirow{2}{*}{$\begin{array}{l}\text { Condi- } \\
\text { tion* }\end{array}$} & \multicolumn{2}{|c|}{ True stress at } & \multirow{2}{*}{$\begin{array}{l}\text { True strain } \\
\text { at Rupture } \\
\%\end{array}$} & \multirow[b]{2}{*}{$\begin{array}{c}\text { Elong.(4d) } \\
\%\end{array}$} & \multirow{2}{*}{$\begin{array}{c}\text { Yield } \\
\text { strength** } \\
\mathrm{kg} / \mathrm{mm}^{2}\end{array}$} & \multirow{2}{*}{$\begin{array}{l}\text { Tensile } \\
\text { strength } \\
\mathrm{kg} / \mathrm{mm}^{2}\end{array}$} \\
\hline & & $\begin{array}{c}\operatorname{Max} .10 \mathrm{~d} d \\
\mathrm{~kg} / \mathrm{mm}^{2}\end{array}$ & $\begin{array}{l}\text { Rupture } \\
\mathrm{kg} / \mathrm{mm}^{2}\end{array}$ & & & & \\
\hline \multirow{2}{*}{ N3B } & $\mathrm{R}$ & 68.0 & 99.5 & 0.84 & 35.4 & 35.5 & 59.0 \\
\hline & $\mathrm{N}$ & 71.0 & 107.1 & 1.16 & 35.6 & 34.0 & 59.0 \\
\hline \multirow{2}{*}{ Y6 B } & $\mathrm{R}$ & 65.0 & $82 . \overline{2}$ & 0.58 & $35 . \overline{4}$ & 34.5 & 55.5 \\
\hline & $\mathrm{N}$ & 67.0 & 113.0 & 1.02 & 38.3 & $37.4(35.1)$ & 54.0 \\
\hline \multirow{2}{*}{$\mathrm{K} 4 \mathrm{~T}$} & $\mathrm{R}$ & 66.0 & 90.9 & 0.83 & 37.7 & 33.1 & 53.5 \\
\hline & $\mathrm{N}$ & 66.5 & 112.3 & 1.01 & 42.8 & $36.8(34.5)$ & 53.8 \\
\hline \multirow{2}{*}{$\mathrm{K} 4 \mathrm{~B}$} & $\mathrm{R}$ & 68.0 & 81.0 & 0.99 & 47.7 & 35.5 & 55.8 \\
\hline & $\mathrm{N}$ & 67.0 & 110.2 & 1.19 & 43.4 & $38.2(35.5)$ & 55.2 \\
\hline \multirow{2}{*}{ K1 B } & $\mathrm{R}$ & 66.0 & 75.0 & 0.88 & 36.7 & 32.5 & 55.5 \\
\hline & $\mathrm{N}$ & 67.0 & 109.0 & 1.00 & 39.4 & $38.2(36.0)$ & 55.5 \\
\hline \multirow{2}{*}{ M 6} & $\mathrm{R}$ & 68.0 & 107.0 & 0.96 & 二 & 32.5 & 58.0 \\
\hline & $\mathrm{N}$ & 70.0 & 108.3 & 1.24 & 35.9 & - & 60.3 \\
\hline
\end{tabular}

* $R$ : As rolled, $N$ : Normalized

$\dagger$ True strain $=\ln$ ( $\mathrm{min}$. cross sectional area)/(original area) ** ( ) means lower Y.P.

\section{7 結 論}

供試高援力鋼の瓦延状態の材質の比較としてVーシャル ピー試験および丸棒引张試駼を行った結果仗次の如く結諭 される.

（1）供試高张力鋼は燃準によってVンャルピ一衛撃試験 の逞移温度が生延のまり状態よりも著しく改善された。 たよ゙脱酸に $\mathrm{Al}$ を用いない $\mathrm{K} 1 \mathrm{~B}, \mathrm{~K} 4 \mathrm{~B}, \mathrm{~K} 4 \mathrm{~T}$ などで方一 ステナイト精度む粗く，遷移温度改善があまり認められな かった。
(2) 㓗準の場合の $\operatorname{Tr}_{15}$ 遷 移温度之 Si 星の関係から $0.6 \%$ 程度までは Si 量が増 加してもあまり遷移温度の 変化は認められないようて ある.

(3) 丸棒による引张試験 結果では，焼準により伸び 影よび断面收縮率が压延状 態よりもかなり増加する. また引張り強さおよび降 伏点は供試鋼 (Mn-Si 系) ではほとんど影暗されなか った.

終りに本研究に種々積極 的な協力を惜しまなかった日本銅管川崎技術研究所垪川係 長经か諸氏执び当熔接部小會研究員ならびそ実験を担当 された当部貣石河技官に感謝の意を表わす次第である.

\section{文献}

1）木原，鈴木，田村；熔接学会誌 本号

2) T.N. Armstrong, N.A. Kahn \& H. Thielsch : Jul. $1952,371-\mathrm{s}-380-\mathrm{s}$

\title{
マンガンンリコン系高張力鋼の簢易脆性試驗*
}

\section{渡辺正紦茁口義治** 山口常昭**森井春生***}

\section{Simplified Notch Toughness-Tests on Mn-Si High Tensile Steels*}

By M. Watanabe,** Y. Ideguchi,** T. Yamaguchi,** and H. Morii***

\begin{abstract}
Customary transition-temperature tests generally require too much material and are very laborious. In a previous report ${ }^{1)}$, one of the authors suggested a simple testing method to evaluate the notch toughness of materials, so-called simplified notch toughness test which was based upon the experimental results of structural mild steels. This method uses the properties that the values of $\varphi$ (ratio of true stress to strain at the maximum load in atensile test), $\varphi^{\prime}, \psi$ and $\psi^{\prime}$, which are described in the present paper, are constant within the temperature range of $-80^{\circ} \mathrm{C}$ to $100^{\circ} \mathrm{C}$ and that the material having the smaller values of $\varphi, \varphi^{\prime}, \psi$ or $\psi^{\prime}$ shows the lower transition temperature.

The purpose of this report is studying the applicability of above mentioned simplified notch toughness test on various structural high tensile steels.

The test results obtained were almost the same with that shown in the structural mild steels ${ }^{1)}$ except, the temperature range in which the value of $\varphi$ or $\varphi^{\prime}$ is constant as seen in Fig. 9 and Fig. 10 . Moreover authors confirmed that $\varphi$ or $\varphi^{\prime}$ obtained by room temperature test can be adopted as an index of the notch toughness of high tensile steels.
\end{abstract}

*(昭和30年 4 月春季学術講演会飞捺いて発表) **正員, 大阪大学工学部 Member, Engineering Faculty, Osaka University *** 正員, 汽車製造株式会社 Member, Kisha Seizo Co. 


\section{1 緒訇}

従来一般に脆性破㙥飞関して切欠勒性なる言葉が使用さ れ，材料の切久勒性の判定に法いわゆる嵒移温度を求める 方法がとられている. しかし実際問題として遷移温度を一 々求めるとと烦煩雑であるから，一般から容易炕実施し得 る普通の常温機械試験結果から材料の切久勒性が判定でき ればきわめて便利である.か力る見地より筆者の一人は先

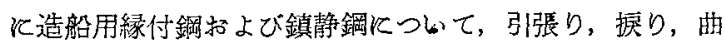
げ試験を $-80^{\circ} \mathrm{C}$ より $200^{\circ} \mathrm{C}$ の各温度に括いて実施し詳 細火吟味した結果低温に括汸る種々の著しい特性を胃出し た.

\section{すなわ方}

丸棒引張試騒江和いて $\varphi=\frac{\text { 最大荷重点に和ける真応力 }}{\text { 最大荷重点飞括りる歪 }}$

切欠曲げ試験に括いて

$$
\varphi^{\prime}=\frac{\text { 最大荷 重 }}{\text { 最大荷重点の撓み星 }}
$$

闌側切欠引張試験飞招いて

$$
\psi=\frac{\text { 最大荷 重 }}{\text { 最大倚重点の伸ひ }}
$$

掭り試験法いて

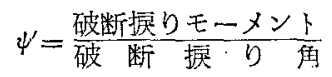

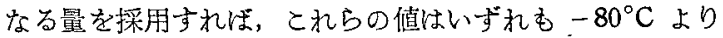

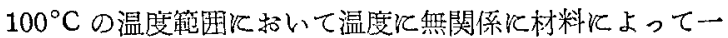
定の值を示し，加㟟移温度の高い村料程これらの值は大 きくなるということが明らかになった。これより軟錄に対 する切久鞄性の简単な方法として $\varphi ， \varphi^{\prime} ， \psi ， \psi^{\prime}$ を採用する ことを提案した ${ }^{1)}$.

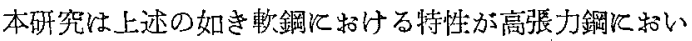
ても存在するや否やを調査することを目的としたもので， 引张試験と切欠州代試験を行い $\varphi$ と $\varphi^{\prime}$ について吟味する こととした。

\section{2 供 試 材 料}

試験材料は代表的な本邦製鋼所より供給せられた高張力 鋼11種類である. 各製鎆所より添村された各材料の化学成

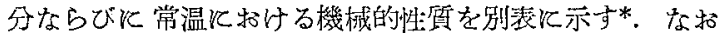
同表中の記号はそれぞれ本報告の次の記号に相当する。

$$
\begin{aligned}
& \text { N3 } \cdots \text { A, N5 } \cdots \mathrm{B}, \mathrm{Y} 4 \cdots \mathrm{C}, \mathrm{Y} 6 \cdots \mathrm{D}, \mathrm{K} 1 \cdots \mathrm{E}, \mathrm{K} 4 \cdots \mathrm{F} \text {, } \\
& \mathrm{M} 3 \cdots \mathrm{G}, \mathrm{M} 6 \cdots \mathrm{H}
\end{aligned}
$$

Tは鋼堍頭部， Bは底部をあらわす。

\section{3 試 験 方 法}

実施せる試験は標準ンヤルピーVノツチ試験片による切 欠曲げ試験と引張試験である.いずれもアムスラ一型10屯 万能試験機を使用し，切矢曲げ試駼に㔚々ては bending punch の直径をンヤルピー衝撃試験の knife-edge.の直径 と同寸法にし，支持条件もまたンヤルピー試験機の場合？ 同棣にして静かに曲げた。

常温以下の温度はドライアイスとアルコールを使用し， 高温側は曲げ試験に括いては油を加熱して温度調節を行い 引張試験は普通の電気炉を使用した，両試験とも恒温槽中 で行った**. Fig.1はこれらの試験片の寸法形状を示す。

\section{4 実験結果ならびに考察}

各種温度で行った引張試駼結果を従来の方式により図示 すると Fig. 2 の如くである. 試験材11種とも類似の傾向 を示しているので図には代表的なるの三種のみをからげる ことつした．これより最大荷重点飞括ける真応力，局張強 さは温度㦀下と共徐々に上昇している。これらの值は軟

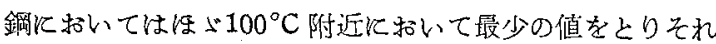
より温度が上昇するに従い再び大きくなっている***，伸，

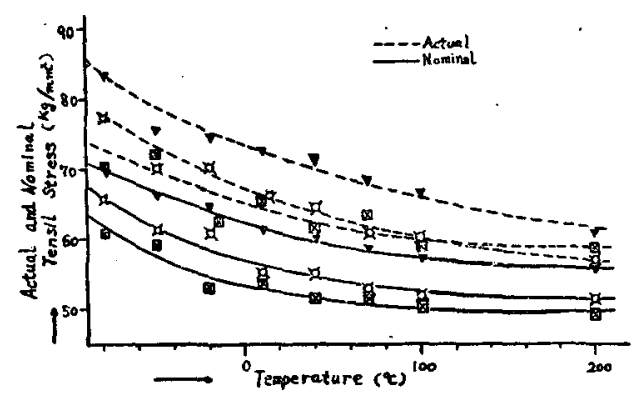

Fig. 2 Relation between temperature and actual tensile stress, or nominal tensile stress

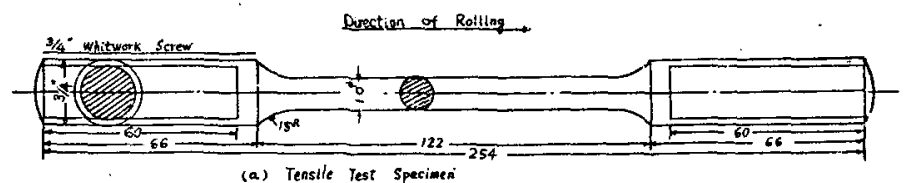

(a) Teasile Test Specimen

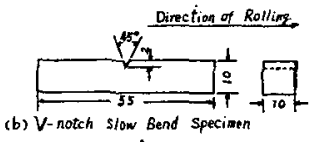

Fig. 1 Details of specimens
最大荷重点の歪はある温㡲以下で降下するよ

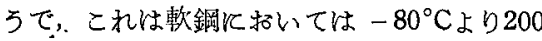
${ }^{\circ} \mathrm{C}$ の温度簿团では見られなかった現象であ

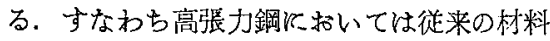
試験結果の表示汇よる延性の城少し始める温

$*$ 総括第 2 表
これら試験装置は交献 $2 \cdot 3$ のむのと
同し装置である.
*** 文献 1 参照


度が軟鋼に比し熟温側飞ある。

切欠曲げ試験より得伦結果は Fig. 3, Fig. 4 飞示すよう でそれそれの遷移㤔線より求めた遷移温度を表示すると Table 1 の通りである.

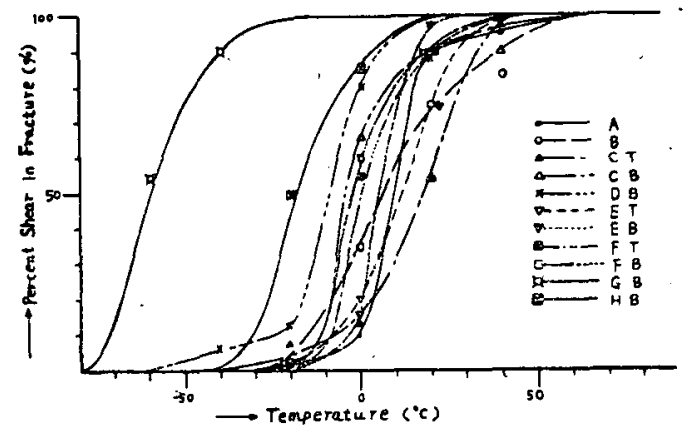

Fig. 3 Relation between temperature and percent shear in facture

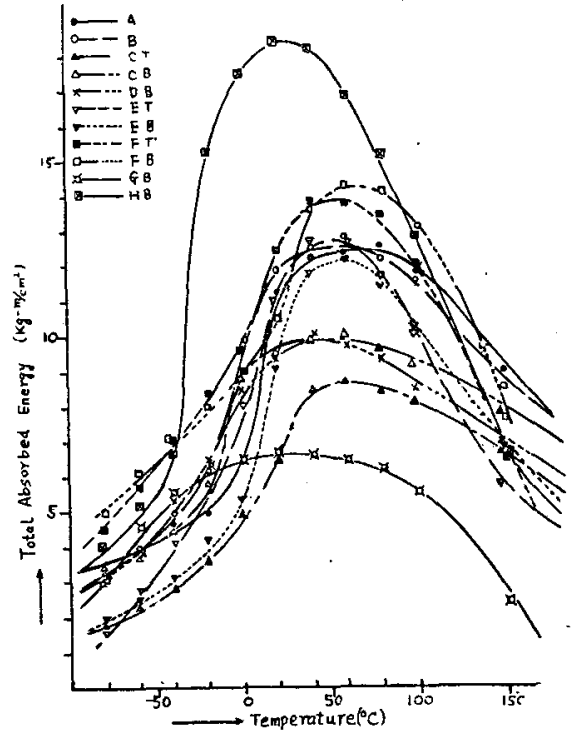

Fig. 4 Relation between temperature and total absorbed energy

Table 1 V-notch Slow Bend Transition Temperature

\begin{tabular}{|c|c|c|c|c|c|c|c|c|c|c|c|}
\hline Material & A & B & CT & $\mathrm{CB}$ & $\mathrm{DB}$ & ET & EB & FT & $\mathrm{FB}$ & GB & HB \\
\hline $\operatorname{Tr}_{1}$ & & & & & & & +14 & + & +12 & -64 & -30 \\
\hline $\operatorname{Tr}_{E t}$ & 17 & & & & 42 & -12 & + & -40 & -36 & -76 & -35 \\
\hline $\operatorname{Tr}_{S}$ & & & & & & & & & + & -60 & -18 \\
\hline
\end{tabular}

$\operatorname{Tr}_{H}$ : Transition temperature determined by absorbed energy after Max. Load

$\operatorname{Tr}_{B t}$ : Transition temperature determined by total absorbed energy

Trs: Transition temperature determined by percent shear. in fracture

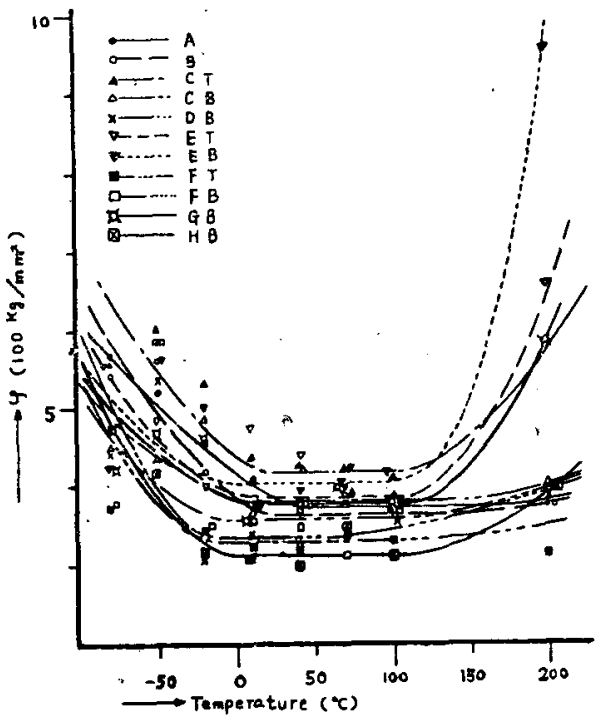

Fig. 5 Relation between temperature and $\varphi$.

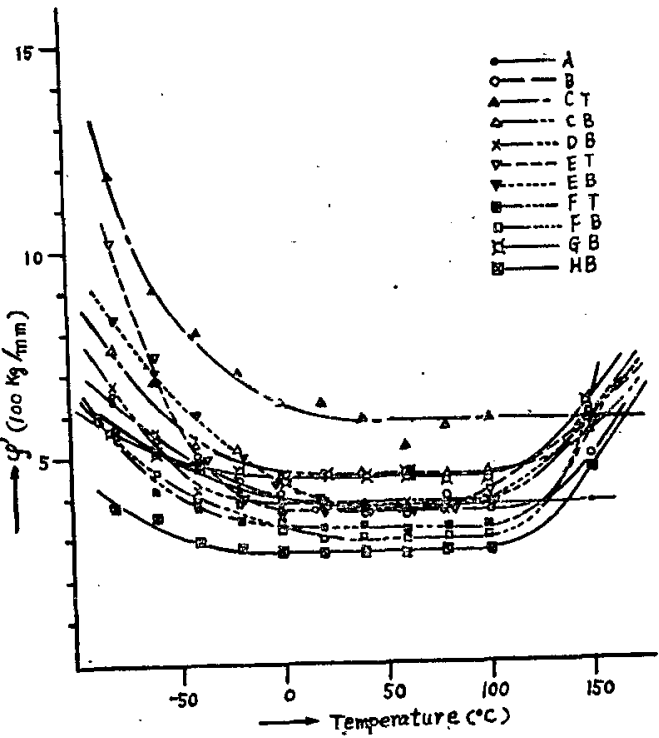

Fig. 6 Relation between temperature and $\varphi^{\prime}$.

Fig. 5, Fig. 6 は前迅した軟鋼の切久䓪性の間易判定 法として提案された Criterion $\varphi, \varphi^{\prime}$ を図示したもので 各值の上萃し始める温度が高温側に移動したこと* を除 けば軟鋼と同様な傾向を示す。すなわち常温より $100^{\circ} \mathrm{C}$ の温度範囲に和いては試験温度に無関係に一定值をとり しかも Fig. 7, Fig. 8, Fig. 9 飞示寸如く遷移温度と $\varphi$ と

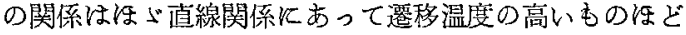
$\varphi$ 值は大となっている。

$\varphi^{\prime}$ と遷移温度との関係怔 $\varphi$ の如き直線関係とはなら

* 引張試験結果よりも当然予期される現象である 


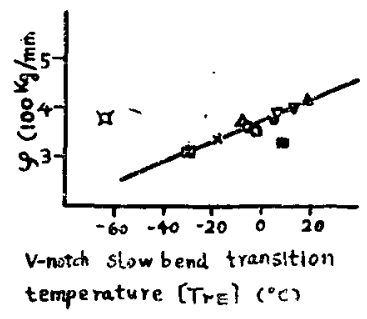

Fig. 7 Relation between $\varphi$ and transion temperature.

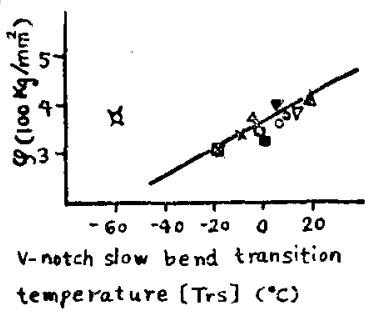

Fig. 8 Relation between $\varphi$ and transion temperature.

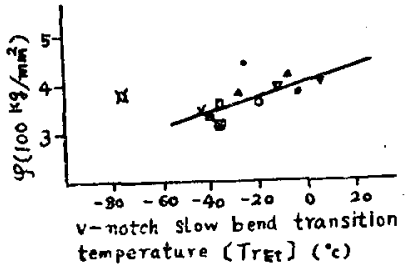

Fig. 9 Relation between $\varphi$

and transion temperature.
ないがいずれにしてもこの值の大なるほど瑟い結果を示す 事は明らかなようで，との関係を明らかにするにはさらに 多くの実験資料を要すると思われる。

\section{5 結喜}

以上軟鋼认対寸る炀久勒性の簡易判定法として提案され た Criterionの中で $\varphi, \varphi^{\prime}$ そついて高張力鋼に用いて検討

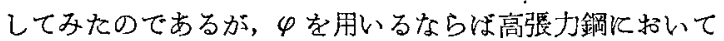
あ軟鋼と同様な特性のみられることが確認された。よって

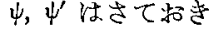
本実呀結果上りみ るならば高偓力鋼 の切欠䩓性の簡易 な判定には $\varphi^{\prime} よ り$ むりを採用する方 が好ましいように 思われる。

\section{文献}

1) Watanabe \& Goda "Corelation of The Notch Toughness of Material to Mechanical Testing Results" Brittle Fracture in Mild Steel and their Welded Joints. The Japan Society of Naval Architect

2）渡辺,合田「鋼材の切欠感度と引張試験結果との比較」 熔接学会誌 第 21 巻 4 号 昭和 27 年

3）渡辺，合田「鋼材切欠感度飞関する切欠曲げ武験」同 上 第 21 巻 3 号昭和 27 年

\title{
マンガンンリコン系高張力鋼のンユナット試驗”
}

\section{吉 識 雅 夫** 金 沢 武**}

\section{Schnadt Test of High Tensile Mn-Si Steels*}

By M. Yoshiki,** T. Kanazawa**

\begin{abstract}
Schnadt Test of Mn-Si high tensile steels, $12 \mathrm{~mm}$ thickness, were executed.

The following conclusions are obtained from the test results about the steels tested :

(1) With the exception of $\mathrm{K}-1, \mathrm{Y}-4$ and $\mathrm{M}-6$, the notch ductility of the tested steels are excellent. However, it is worth notice that the maximum absorbed energies of $\mathrm{N}-3$ and $\mathrm{N}-6$ are considerably lower than that of the other steels.

(2) There are clear correlations between the transition temperatures obtained by Schnadt and Charpy Test. There are no significant superiority between these two tests.
\end{abstract}

\section{1 緒 言}

本報告は日本造船研究協会第六研究部会に括いて「MnSi 系高張力鋼の熔接性の研究」のために試作された高張 力鋼の中，板厚 $12 \mathrm{~mm}$ のむのについてンュナット試験を 実施し，これら鎆材の有する切久感度を判定し，あわせて 別に行われたンャルピ一試験結果と比較検討したものであ

* 原稿受付 昭和 30 年 8 月 11 日（昭和30年度撘接学会 春季学術講演会比扮いて器表)

** 正員, 東京大学工学部 Member Faculty of Engineering, Tokyo University
る.

\section{2 試験用鋼材，試験片形狀および試験方法}

\section{2-1 誌験用鋼材}

供試鋼材㤌今回試作された厚さの $12 \mathrm{~mm}$ 高强力鋼 8 種 (N3，N5，Y4，Y6，K1，K4，M3 拉よび M6) で，いずれも 鋼塊の底部より採取したものである*，

\section{$2-2$ 試験片形状}

* M-3，M-6 は鋼塊のどの部分から採取したものか不明 である. 化学成分等については総括第 2 表参照 